\title{
Assessment of Some Sweet Cherry Cultivars in Comparison with Their Genitors under the Conditions of the North-Eastern Area of Romania
}

\author{
Elena IUREA ${ }^{1}$, Sorina SÎRBU ${ }^{1 *}$, Margareta CORNEANU ${ }^{1}$, \\ Mădălina BUTAC², Irina TITIRICĂ², Mădălina MILITARU² \\ ${ }^{1}$ Research Station for Fruit Growing, 175 Voinesti Str., 707305 Iassi, Romania; iurea_elena@yahoo.com; \\ sorinas66@gmail.com (*correspondingauthor);margaretacorneanu@yahoo.com \\ ${ }^{2}$ Research Institute for Fruit Growing Piteşti, 117450 Mărăcineni, Romania; madalinabutac@yahoo.com; \\ irinaancu80@yahoo.com; madamilitaru77@yahoo.com
}

\begin{abstract}
Starting with 1981, the objectives of the breeding programmes in the Research Station for Fruit Growing (RSFG) Iaşi, Romania, took into consideration the on-going improvement of the sweet cherry assortment with cultivars having fruitbearing precocity, with great productions, self-fertile, with decreased trees' vigour, crown compactness, resistant to anthracnose, monilia, frost and fruit's cracking, flowering lateness, superior quality of the fruits and ripening time at the extremities of the sweet cherries' maturation season. As a result of the breeding programmes that took place up till present at RSFG Iaşi, 28 new sweet cherry cultivars, obtained through controlled hybridization, free pollination and conservative clonal selection, were homologated during 1994-2017. The present results refer to a study led during 2015-2017, having as biological material nine sweet cherry cultivars ('Cetățuia', 'Cătălina', 'Golia', 'Bucium', 'Ştefan', 'Iaşirom', 'Oana', 'Radu' and 'Ludovan') obtained through controlled hybridization. The comparision of the cultivars has been performed versus their genitors 'Van' $(q)$ and 'Boambe de Cotnari' $(\hat{O})$. There have been taken observations and determinations concerning the trees' vigour, resistance to frost and anthracnosis, the main growing and fructification phenophases, physical and chemical treats of the fruit. The highest values regarding fruit's weight (7.5-8.9 g) have been recorded for the 'Ludovan', 'Bucium', 'Ştefan', 'Iaşirom' and 'Golia' cultivars, while the values of the soluble substance content have been between 15.20-19.25 'Brix, the titratable acidity has been between $0.455-0.764 \mathrm{~g}$ malic acid $100 \mathrm{~mL}^{-1}$ of fresh juice and the total content of polyphenols has recorded values between 97.41-574.95 mg GAE $100 \mathrm{~mL}^{-1}$ of fresh juice. The hybridization between 'Van' and 'Boambe de Cotnari' has allowed the obtaining of valuable cultivars, that got remarked by earliness ('Cetățuia', 'Cătălina'), decreased trees' vigour ('Ştefan', 'Golia'), particular quality of the fruits ('Ludovan', 'Iaşirom', 'Golia', 'Bucium', 'Ştefan', 'Oana', 'Radu') and resistance to diseases and frost ('Bucium', 'Iaşirom').
\end{abstract}

Keywords: breeding; gallic acid; genotypes; fruit; quality

\section{Introduction}

The sweet cherry is a rustic fruit-growing species, taking into consideration the relatively modest requirements for climate and the crop technology (Cociu et al., 1999). It is a fruit-growing species with great economic importance, given by the nutritive, technological and commercial features of the fruits, that finds in Romania optimal conditions to manifest their agrobiological potential (Grădinariu and Istrate, 2003).

On the fresh fruits' market, the preferred cultivars are the ones of 'Bigarreau' type, with shiny red colour or double coloured, resistant to cracking, transportation and temporary warehousing, with a weight of more than $7 \mathrm{~g}$ (Budan and Grădinariu, 2000; Meland et al., 2014).

In Romania, the concerns for improving the sweet cherry assortment have a long history, the proof being the various local cultivars, from which some have been included in the national assortment (Budan et al., 1997; Cociu and Oprea, 1989).

The objectives of the breeding programmes for the sweet cherry species are similar both at national and global level and take into consideration the obtaining of cultivars with fruit-bearing precocity, productive, self-fertile, decreased trees' vigour, crown compactness, suitability to mechanized harvesting, resistance to anthracnosis, monilia, frost and cracking of the fruits, flowering lateness, superior quality of 
208

the fruits (according to the latest size requirements, firmness, taste and colour) and ripening ages set at the extremities of the cherries' maturation season (Sansavini and Lugli, 2008; Kask et al., 2010; Milatović, 2011; Schuster et al., 2014).

To accomplish some of these objectives, during 19812017, at the Research Station for Fruit Growing (RSFG) Iaşi, there were obtained using controlled hybridization, free pollination and conservative clonal selection, 28 new cherry cultivars that were homologated and patented during 19942017.

The paper presents the valuable characteristics of the new sweet cherry genotypes created in RSFG Iaşi, compared with their genitors 'Van' ( $(+)$ and 'Boambe de Cotnari' $\left({ }^{\Uparrow}\right)$, that improve the autochthonous assortment.

\section{Materials and Methods}

\section{Biologicalmaterial}

The present studies were performed during 2015-2017, having as research material, nine sweet cherry genotypes ('Cetă̆țuia', 'Cătălina', 'Golia', 'Bucium', 'Ştefan', 'Iaşirom', 'Oana', 'Radu' and 'Ludovan'). Two out of the nine studied genotypes present early maturation ('Cetățuia', 'Cătălina'), while the other seven present average maturation ('Golia', 'Bucium', 'Ştefan', 'Iaşirom', 'Oana', 'Radu' and 'Ludovan'). To create the nine sweet cherry genotypes, cultivars 'Van' and 'Boambe de Cotnari' have been used as genitors. The method to create the new cultivars has been the classic one, meaning that controlled sexuated hybridizations has been performed, along with hybrid fruit stones harvesting, obtaining hybrid saplings, selecting and testing the hybrids according to the established objectives (Cociu and Oprea, 1989; Petre, 2007).

The selected elites have been grafted on mahaleb, whereupon they have been planted in field trials at linear variants at a distance of $4 \times 5 \mathrm{~m}$. Each variant contained nine trees, formed from three repetitions of three trees each, the variants being positioned in randomized blocks. The trees have been led as free palmette, limited in height and flattened on the direction of the row, without sustaining and irrigation systems.

The comparison of the cultivars has been performed versus their genitors 'Van' (O) and 'Boambe de Cotnari'(ð)).

\section{Experimental procedures}

During the experimental field, there have been performed observations and determinations concerning the trees' vigour, resistance to frost and anthracnose (Cociu and Oprea, 1989), the main growing and fructification phenophases (Fleckinger, 1960), the physical traits (fruit's weight, fruit's equatorial diameter, fruit's colour), chemical traits (soluble dry substance, titratable acidity, ratio between the soluble dry substance and titratable acidity, total polyphenols content) and the organoleptic and quality traits of the fruits (the taste of the fruit, the firmness of the pulp, the shape of the fruit, the stone's adherence to pulp, the fruit's resistance to cracking) (UPOV, 2006).

\section{Physical traits}

The physical traits of the fruit have been measured as follows: the weight $(\mathrm{g})$ by weighting 10 fruits in three repetitions with the electronic balance Radwag type $0.01 \mathrm{G}$ accuracy. Fruit's dimensions as equatorial diameter of the fruit (D) have been measured with the digital calliper Luumytools on 10 fruits in three repetitions. Fruit's colour has been measured according to the questionnaire UPOV TG/35/7, with marks between 1-8. Fruit's shape has been measured according to the questionnaire UPOV TG/35/7, with marks between 1-5.

\section{Chemical and quality features of the fruits}

The chemical and quality features of the fruits have been measured as follows: the soluble dry substance has been measured refractometric using a Zeiss refractometer and expressed in Brix degree; the titratable acidity of the fruits has been measured through the potentiometric method (Ghimicescu, 1977) and expressed in $\mathrm{g}$ malic acid $100 \mathrm{~mL}^{-1}$ of fresh juice. Total polyphenols content has been performed using the Folin-Ciocalteu method (Jayaprakasha et al., 2001). Pulp firmness has been measured by taste the fruit with marks between 3 to 9 according to the questionnaire UPOV TG/35/7 (2006). Fruit's flavour has been measured by taste with marks between 3 to 7 according to the questionnaire UPOV TG/35/7 (2006). Pulp's adherence to the stone has been measured also by tasting.

Fruit's resistance to cracking has been determined by soaking 100 fruits from each cultivar in distilled water and after 6 hours the number of cracked fruits was checked and expressed in percent of cracking per cultivar (Cociu and Oprea, 1989).

\section{Statistical procedures}

The experimental data has been statistically interpreted by analysing the variance and the multiple comparisons method by Duncan test, with P 5\%.

\section{Results}

Regarding the trees' vigour, it must be highlighted that cultivars 'Ştefan' and 'Golia' recorded a decreased vigour, while the other cultivars had an average vigour. Regarding the resistance to frost, during 19-21 $1^{\text {st }}$ of April 2017, when the sweet cherry was blooming, there were recorded minimum temperatures down to $-2.5^{\circ} \mathrm{C}$, which made the branches of the trees to be covered with a layer of snow of approximately $10 \mathrm{~cm}$ for a period of time longer than 24 hours.

Statistically, the most affected cultivars have been 'Ştefan' (75\%) and 'Golia' (69\%) which have recorded significant positive values and respectively very significant positive values in comparison with the genitors of the cultivar 'Van' (62\%) and 'Boambe de Cotnari' (64\%) respectively. 'Bucium' (57\%) has recorded significant negative values in comparison with the maternal genitor 'Van' (62\%) (Table 1).

Concerning the resistance to diseases, 2016 being a rainy year (with a surplus of $173 \mathrm{~mm}$ compared with multiannual 
values), favourable to pathogens (monilia and anthracnosis), all tested cultivars recorded a decreased sensitivity to Coccomyces biemalis Higg. (the attack frequency was between 1.9-4.2\%) (Table 1).

The end of flowering in the sweet cherry cultivars studied during 2015-2017 was recorded between 08 and $26^{\text {th }}$ of April.

The harvesting maturity was recorded in the second and third decades of May ('Cetățuia' and 'Cătălina'), respectively in the first and second decades of June ('Golia', 'Bucium', 'Ştefan', 'Iaşirom', 'Oana', 'Radu' and 'Ludovan'). The average number of days between the end of flowering and harvesting maturity was between 33-39 days for the sweet cherry cultivars with early maturation ('Cetățuia' and
'Cătălina') and 50-57 days for the cultivars with maturation in medium season ('Golia', 'Bucium', 'Ştefan', 'Iaşirom', 'Oana', 'Radu' and 'Ludovan'). Statistically, the cultivar 'Ştefan' has recorded significantly negative differences, while the cultivars 'Cetățuia' and 'Cătălina' have recorded very significantly negative differences, in comparison with their genitors ('Van' and 'Boambe de Cotnari') (Table 2).

The cultivars with the largest fruit sizes have been 'Ludovan', 'Bucium', 'Ştefan', 'Iaşirom' and 'Golia' (with a weight between 7.5-8.9 $\mathrm{g}$ and an equatorial diameter between 23.2-26.2 mm). Under the aspect of fruit's size, respectively the average weight and equatorial diameter of the fruit, data were comparable or superior to the genitors of the studied cultivars (Table 3 ).

Table 1. Cherry tree's vigour, resistance to frost and anthracnosis (RSFG Iasi; 2015-2017)

\begin{tabular}{|c|c|c|c|c|c|c|}
\hline \multirow{4}{*}{ Cultivar } & \multirow{4}{*}{$\begin{array}{l}\text { Tree's } \\
\text { vigour }^{1}\end{array}$} & \multirow{2}{*}{\multicolumn{2}{|c|}{$\begin{array}{l}\text { Resistance to frost in the complete flowering } \\
\text { phenophase - (\% affected ovaries })^{2} \text { - }\end{array}$}} & \multicolumn{3}{|c|}{ Resistance to anthracnosis (Coccomyces hiemalis Higg.) } \\
\hline & & & & \multirow{3}{*}{$\mathrm{F}(\%)$} & \multirow{3}{*}{$\mathrm{I}(\%)^{3}$} & \multirow{3}{*}{ GA $(\%)$} \\
\hline & & Calculated versus & \multirow{2}{*}{ Calculated versus 'Van’ (q) } & & & \\
\hline & & 'B. Cotnari' (ふొ) & & & & \\
\hline 'Cetățuia' & 5 & 62 & 62 & 1.9 & 5 & 0.04 \\
\hline ‘Cătălina’ & 5 & 66 & 66 & 3.1 & 5 & 0.06 \\
\hline ‘Golia’ & 3 & $69^{*}$ & 69 & 3.1 & 5 & 0.06 \\
\hline 'Bucium’ & 5 & 57 & 57 & 2.9 & 5 & 0.06 \\
\hline 'Ştefan' & 3 & $75^{* * *}$ & $75^{* *}$ & 3.5 & 10 & 0.07 \\
\hline 'Iaşirom' & 5 & 60 & 60 & 2.7 & 5 & 0.05 \\
\hline 'Oana' & 5 & 63 & 63 & 3.5 & 5 & 0.07 \\
\hline 'Radu’ & 5 & 63 & 63 & 3.3 & 5 & 0.07 \\
\hline 'Ludovan' & 5 & 65 & 65 & 4.2 & 10 & 0.08 \\
\hline 'Van’ (q) & 5 & 62 & 62 & 2.2 & 10 & 0.04 \\
\hline 'Boambe de Cotnari' $(\widehat{\jmath})$ & 5 & 64 & 64 & 3.8 & 5 & 0.08 \\
\hline
\end{tabular}

'UPOV test: tree's vigour mark on a scale of 1-9:3 = weak; 5 = average (UPOV, 2006);

${ }^{2}$ LSD $5 \%=6.1 \%$; LSD $1 \%=8.3 \%$; LSD $0.1 \%=11.3 \%$;

3 Attack intensity mark (1-6 scale): $1=1-3 \%$ attacked surface; $2=4-10 \% ; 3=11-25 \% ; 4=26-50 \% ; 5=51-75 \% ; 6=76-100 \%$ (Cociu and Oprea, 1989$)$.

Table 2. End of flowering date, harvesting period and the number of days between the end of flowering and fruit's maturation in sweet cherry cultivars (RSFG Iasi; 2015-2017)

\begin{tabular}{|c|c|c|c|c|c|}
\hline \multirow{2}{*}{ Cultivar } & \multirow{2}{*}{$\begin{array}{c}\text { End of flowering } \\
\text { (date) }\end{array}$} & \multirow{2}{*}{$\begin{array}{l}\text { Harvesting period } \\
\text { (date) }\end{array}$} & \multirow{2}{*}{$\begin{array}{l}\text { Average number of days } \\
\text { between the end of } \\
\text { flowering and harvesting } \\
\text { period }^{1}\end{array}$} & \multicolumn{2}{|c|}{$\begin{array}{l}\text { Calculated versus the cultivars' genitors } \\
\text { (no. of days })^{2}\end{array}$} \\
\hline & & & & 'Van' (中) & 'Boambe de Cotnari' ( $\left.{ }^{\Uparrow}\right)$ \\
\hline 'Golia' & $14 \mathrm{IV}-24 \mathrm{IV}$ & $06 \mathrm{VI}-12 \mathrm{VI}$ & $57^{a}$ & +1 & +2 \\
\hline 'Radu' & $09 \mathrm{IV}-22 \mathrm{IV}$ & $07 \mathrm{VI}-15 \mathrm{VI}$ & $57^{a}$ & +1 & +2 \\
\hline 'Ludovan' & $14 \mathrm{IV}-23 \mathrm{IV}$ & $10 \mathrm{VI}-16 \mathrm{VI}$ & $56^{a}$ & 0 & +1 \\
\hline 'Van'(q) & $14 \mathrm{IV}-26 \mathrm{IV}$ & $11 \mathrm{VI}-17 \mathrm{VI}$ & $56^{a}$ & - & - \\
\hline 'Boambe de Cotnari' (ภ̊) & $12 \mathrm{IV}-22 \mathrm{IV}$ & $08 \mathrm{VI}-12 \mathrm{VI}$ & $55^{\mathrm{b}}$ & - & - \\
\hline 'Bucium’ & $14 \mathrm{IV}-24 \mathrm{IV}$ & $07 \mathrm{VI}-18 \mathrm{VI}$ & $55^{\mathrm{b}}$ & -1 & 0 \\
\hline 'Oana' & $10 \mathrm{IV}-22 \mathrm{IV}$ & $06 \mathrm{VI}-12 \mathrm{VI}$ & $55^{\mathrm{b}}$ & -1 & 0 \\
\hline 'Iaşirom’ & $12 \mathrm{IV}-23 \mathrm{IV}$ & $08 \mathrm{VI}-10 \mathrm{VI}$ & $53^{\mathrm{b}}$ & -3 & -2 \\
\hline 'Ştefan' & $14 \mathrm{IV}-26 \mathrm{IV}$ & $06 \mathrm{VI}-10 \mathrm{VI}$ & $50^{b}$ & -6 & $-5^{\circ}$ \\
\hline 'Cătălina' & $10 \mathrm{IV}-22 \mathrm{IV}$ & $17 \mathrm{~V}-31 \mathrm{~V}$ & $39^{c}$ & $-17^{\text {soe }}$ & -16 \\
\hline ‘Cetățuia’ & $08 \mathrm{IV}-20 \mathrm{IV}$ & $11 \mathrm{~V}-22 \mathrm{~V}$ & $33^{\mathrm{d}}$ & $-23^{\circ+0}$ & -22 \\
\hline
\end{tabular}

Tdifferent letters correspond with the significant statistical difference for $\mathrm{P} \leq 5 \%$, Duncan test;

${ }^{2} \operatorname{LSD} 5 \%=5$ days; $\operatorname{LSD} 1 \%=7$ days; $\operatorname{LSD} 0.1 \%=9$ days. 
Table 3. The fruit's weight and equatorial diameter in cherry cultivars (RSFG Iasi; 2015-2017)

\begin{tabular}{|c|c|c|c|c|c|c|}
\hline \multirow[t]{2}{*}{ Cultivar } & \multirow{2}{*}{$\begin{array}{c}\text { Average } \\
\text { weight of the } \\
\text { fruit }(\mathrm{g})^{1}\end{array}$} & \multicolumn{2}{|c|}{$\begin{array}{l}\text { Calculated versus the cultivars' genitors } \\
\qquad(\mathrm{g})^{2}\end{array}$} & \multirow{2}{*}{$\begin{array}{c}\text { Fruit's equatorial } \\
\text { diameter } \\
(\mathrm{mm})^{1}\end{array}$} & \multicolumn{2}{|c|}{$\begin{array}{l}\text { Calculated versus the cultivars genitors } \\
\qquad(\mathrm{mm})^{3}\end{array}$} \\
\hline & & 'Van' (Q) & 'Boambe de Cotnari' (Љ) & & 'Van'() & 'Boambe de Cotnari' (ठ઼) \\
\hline 'Ludovan' & $8.9^{\mathrm{a}}$ & $+1.8^{*}$ & +1.5 & $26.2^{\mathrm{a}}$ & $+2.9^{* * *}$ & $+2.5^{* *}$ \\
\hline 'Bucium' & $8.5^{\mathrm{b}}$ & +1.4 & +1.1 & $25.0^{\mathrm{b}}$ & $+1.7^{*}$ & +1.3 \\
\hline 'Ştefan' & $8.4^{\mathrm{b}}$ & +1.3 & +1.0 & $24.3^{\mathrm{bc}}$ & +1.0 & +0.6 \\
\hline 'Iaşirom' & $8.2^{\mathrm{b}}$ & +1.1 & +0.8 & $24.6^{\mathrm{bc}}$ & +1.3 & +0.7 \\
\hline 'Golia' & $7.5^{\mathrm{c}}$ & +0.4 & +0.1 & $23.2^{\mathrm{cd}}$ & -0.1 & -0.5 \\
\hline 'Boambe de Cotnari' (১) & $7.4^{c}$ & - & - & $23.7^{\text {cd }}$ & - & - \\
\hline 'Cătălina' & $7.3^{\mathrm{c}}$ & +0.2 & -0.1 & $23.8^{\text {cd }}$ & +0.5 & +0.1 \\
\hline 'Van' $(q)$ & $7.1^{\mathrm{c}}$ & - & - & $23.3^{\mathrm{cd}}$ & - & - \\
\hline 'Radu' & $7.0^{c}$ & -0.1 & -0.4 & $23.0^{\mathrm{cd}}$ & -0.3 & -0.7 \\
\hline 'Oana' & $6.7^{\mathrm{c}}$ & -0.4 & -0.7 & $22.4^{\mathrm{e}}$ & -0.9 & -1.3 \\
\hline 'Cetățuia' & $5.6^{\mathrm{c}}$ & -1.5 & -1.8 & $21.1^{\mathrm{e}}$ & $-2.2^{\circ \circ}$ & $-2.6^{\circ}$ \\
\hline
\end{tabular}

'different letters correspond with the significant statistical difference for $\mathrm{P} \leq 5 \%$, Duncan test;

${ }^{2} \mathrm{LSD} 5 \%=1.8 \mathrm{~g} ; \mathrm{LSD} 1 \%=2.5 \mathrm{~g} ; \mathrm{LSD} 0.1 \%=3.4 \mathrm{~g}$

${ }^{3} \mathrm{LSD} 5 \%=1.5 \mathrm{~mm} ;$ LSD $1 \%=2.1 \mathrm{~mm} ;$ LSD $0.1 \%=2.8 \mathrm{~mm}$

Under the aspect of some physical and organoleptic characteristics of the fruits, the firmness of the pulp was medium for the early genotypes ('Cetățuia', 'Cătălina') and firm for the ones with maturation during the medium season ('Golia', 'Bucium', 'Ştefan', 'Iaşirom', 'Oana', 'Radu' and 'Ludovan').

All the studied cultivars had dark red skin fruit and sweet taste. Regarding the fruits' resistance to cracking, the nine genotypes presented superior resistance in comparison with the genitors of the cultivars 'Van' (44.0\%) and 'Boambe de Cotnari' (20.7\%) (Table 4).
Soluble dry substance ranged between $15.2{ }^{\circ}$ Brix ('Cetățuia') and $19.25^{\circ}$ Brix ('Ștefan') (Table 5).

All the studied cultivars recorded large values of the SDS:TA ratio, but the cultivars 'Iaşirom', 'Ludovan', 'Oana' and 'Radu' have recorded larger values than their genitors (Table 5). Most of the cultivars got remarked with a high polyphenols content also, with values between 235.36574.95 mg GAE $100 \mathrm{~mL}^{-1}$ ('Iaşirom', 'Cătălina', 'Oana', 'Bucium', 'Cetățuia', 'Golia', 'Ştefan' and 'Ludovan') (Table 5).

Table 4. Physical, organoleptic and quality traits of the fruits in the studied cherry cultivars (RSFG Iasi; 2015-2017)

\begin{tabular}{|c|c|c|c|c|c|c|c|c|}
\hline \multirow{2}{*}{ Cultivar } & \multirow{2}{*}{$\begin{array}{l}\text { Epidermis } \\
\text { colour }^{1}\end{array}$} & \multirow{2}{*}{$\begin{array}{c}\text { Pulp } \\
\text { firmness }{ }^{2}\end{array}$} & \multirow{2}{*}{$\begin{array}{l}\text { Fruit's } \\
\text { shape }^{3}\end{array}$} & \multirow{2}{*}{$\begin{array}{l}\text { Pulp adherence to } \\
\text { stone }\end{array}$} & \multirow{2}{*}{ Taste $^{4}$} & \multirow{2}{*}{$\begin{array}{l}\text { Cracked fruits } \\
\text { after six hours } \\
\qquad \%)^{5}\end{array}$} & \multicolumn{2}{|c|}{$\begin{array}{c}\text { Calculated versus the cultivars' } \\
\text { genitors }(\%)^{6}\end{array}$} \\
\hline & & & & & & & 'Van’ (q) & $\begin{array}{l}\text { 'Boambe de } \\
\text { Cotnari' }(\widehat{\jmath})\end{array}$ \\
\hline 'Van'(q) & 7 & 7 & 4 & non-adherent & 7 & $44.0^{a}$ & - & - \\
\hline 'Bucium' & 7 & 7 & 1 & non-adherent & 5 & $34.0^{\mathrm{b}}$ & -10.0 & +13.3 \\
\hline 'Ştefan' & 7 & 7 & 1 & non-adherent & 5 & $23.0^{c}$ & $-21.0^{\circ}$ & +2.3 \\
\hline 'Boambe de Cotnari’ (১) & 2 & 7 & 1 & non-adherent & 5 & $20.7^{\mathrm{d}}$ & - & - \\
\hline ‘Cetățuia’ & 7 & 5 & 2 & semiadherent & 5 & $16.0^{\mathrm{e}}$ & $-28.0^{\infty}$ & -4.7 \\
\hline 'Golia' & 7 & 7 & 1 & non-adherent & 7 & $7.0^{f}$ & $-37.0^{\infty}$ & -13.7 \\
\hline 'Cătălina' & 7 & 5 & 1 & non-adherent & 5 & $6.3^{f}$ & $-37.7^{\infty}$ & $-14.4^{\circ}$ \\
\hline 'Oana' & 7 & 7 & 2 & non-adherent & 5 & $4.3^{\mathrm{f}}$ & $-39.7^{\infty 00}$ & $-16.4^{\circ}$ \\
\hline 'Radu' & 7 & 7 & 2 & non-adherent & 5 & $2.7^{f}$ & $-41.3^{\infty}$ & $-18.0^{\circ}$ \\
\hline 'Ludovan' & 7 & 7 & 2 & non-adherent & 7 & $2.3^{\mathrm{f}}$ & $-41.7^{\infty}$ & $-18.4^{\circ}$ \\
\hline 'Iaşirom' & 7 & 7 & 1 & non-adherent & 7 & $0.7^{f}$ & $-43.3^{\infty}$ & $-20.0^{\infty}$ \\
\hline
\end{tabular}

${ }^{T}$ UPOV test: skin colour mark on a scale of 1-8: 1 = yellow; 2 = red yellow; 7 = dark red; 8 = black (UPOV, 2006);

${ }^{2}$ UPOV test: pulp firmness mark on a scale of $3-9: 3=$ soft; $5=$ average; $7=$ firm; $9=$ very firm (UPOV, 2006);

${ }^{3}$ UPOV test: fruit's shape mark on a scale of 1-5: 1 = heart-shaped; 2 = kidney-shaped; 4 = circular (UPOV, 2006);

${ }^{4}$ UPOV test: fruit's taste mark on a scale of 3-7:5 = average sweet; 7 = very sweet (UPOV, 2006);

5 different letters correspond with the significant statistical difference for $\mathrm{P} \leq 5 \%$, Duncan test:

${ }^{6}$ LSD $5 \%=14.0 \% ;$ LSD $1 \%=19.0 \%$; LSD $0.1 \%=25.8 \%$. 
Table 5. Soluble dry substance, titratable acidity, polyphenols and the ratio of soluble dry substance/titratable acidity of the fruits in cherry cultivars (RSFG Iasi; 2015-2017)

\begin{tabular}{|c|c|c|c|c|}
\hline Genotype & $\begin{array}{c}\text { SDS } \\
\left({ }^{\circ} \text { Brix }\right)^{*}\end{array}$ & $\begin{array}{c}\text { Titratable acidity } \\
\left(\mathrm{g} \text { malic acid } 100 \mathrm{~mL}^{-1} \text { of fresh juice }\right)^{* *}\end{array}$ & SDS:TA & $\begin{array}{l}\text { Total content of polyphenols } \\
\left(\mathrm{mg} \mathrm{GAE} 100 \mathrm{~mL}^{-1}\right)\end{array}$ \\
\hline 'Van'() & $17.000^{\mathrm{bl}}$ & $0.588^{b}$ & $28.911^{\mathrm{c}}$ & $400.05^{c}$ \\
\hline 'Bucium’ & $19.000^{\mathrm{b}}$ & $0.665^{\mathrm{ab}}$ & $28.571^{\mathrm{c}}$ & $301.17^{\mathrm{d}}$ \\
\hline 'Ștefan' & $19.250^{\mathrm{a}}$ & $0.764^{\mathrm{a}}$ & $25.196^{\mathrm{d}}$ & $252.74^{\mathrm{f}}$ \\
\hline 'Boambe de Cotnari’ (ふ̋) & $17.200^{\mathrm{b}}$ & $0.585^{\mathrm{b}}$ & $29.401^{\mathrm{c}}$ & $97.41^{\mathrm{h}}$ \\
\hline 'Cetățuia' & $15.200^{\mathrm{b}}$ & $0.600^{\mathrm{ab}}$ & $25.333^{\mathrm{d}}$ & $304.65^{\mathrm{d}}$ \\
\hline ‘Golia' & $17.700^{\mathrm{b}}$ & $0.621^{\mathrm{ab}}$ & $28.502^{c}$ & $282.79^{e}$ \\
\hline 'Cătălina' & $19.200^{\mathrm{a}}$ & $0.754^{a}$ & $25.464^{d}$ & $436.31^{\mathrm{b}}$ \\
\hline 'Oana' & $18.000^{\mathrm{b}}$ & $0.572^{\mathrm{cd}}$ & $31.468^{\mathrm{b}}$ & $312.57^{\mathrm{d}}$ \\
\hline 'Radu' & $17.950^{\mathrm{b}}$ & $0.581^{\mathrm{c}}$ & $30.895^{c}$ & $99.94^{\mathrm{h}}$ \\
\hline 'Ludovan' & $17.300^{\mathrm{b}}$ & $0.455^{d}$ & $38.021^{\mathrm{a}}$ & $235.36^{\mathrm{g}}$ \\
\hline 'Iaşirom' & $18.450^{\mathrm{b}}$ & $0.465^{d}$ & $39.677^{a}$ & $574.95^{\mathrm{a}}$ \\
\hline
\end{tabular}

Tdiffertnt letters correspond with the significant statistical difference for $\mathrm{P} \leq 5 \%$, Duncan test;

*SDS = the soluble dry substance;

${ }^{*}$ SDS:TA = the ratio between the soluble dry substance and titratable acidity.

\section{Discussion}

When minimum temperatures down to $-2.5^{\circ} \mathrm{C}$ and branches of the trees were covered with a layer of snow for more than 24 hours, the recently fertilized ovary has been affected and therewith much of the production of fruits has been compromised (Prskavec and Kloutvor, 1986). Hence, the effect of the very low temperatures on the gynoecium in the sweet cherry flowers under the given conditions has been between $57 \%$ in the 'Bucium' cultivar (calculated through the affecting degree of the gynoecium) and $75 \%$ in 'Ştefan'. Garcia et al. (2014) noted that for sweet cherry cultivars with early and middle flowering times is very important to produce enough flowers for a normal early crop. However, the phenological periods for the this type of sweet cherry genotypes are variable according to the climatic conditions of each year, but the order in which the sweet cherry cultivars get to maturity is maintained always the same, excepting the time interval between two successive cultivars which could be longer or shorter (Darbyshire et al., 2012).

The fruit's weight and equatorial diameter are measures influenced by the climatic conditions, the applied technology and the biological particularities of each cultivar (Faniadis et al., 2010; Fotirić Akšić and Nikolić, 2013). Sen et al. (2014) observed weight and fruit firmness loss values of three sweet cherry cultivars during the transport and marketing stages. Bieniek et al. (2011) found $3.78 \mathrm{~g}$ to 6.45 $\mathrm{g}$ as mean of three years mean for the weight of sweet cherry fruits for cultivars grown under the climatic and soil conditions of Warmia, Lithuania, while Demirsoy and Demirsoy (2004) reported for local Turkish sweet cherry cultivars values of fruit weight ranging from 2.9 to $7.6 \mathrm{~g}$.

It is very important for the sweet cherry cultivars to be resistant to cracking also because the cracked fruits lose their commercial value, become perishable and Monilia sp. settles inside the crevice on the fruit and they become inedible. Therefore, the economic efficiency of sweet cherry productions reduces substantially (Milatović, 2011). Values registered of soluble dry substance in accordance with other studies (Jänes et al., 2010). The SDS:TA ratio is considered very important for determining the sweet cherry fruits' taste, reflecting a balance between the sweet and sour taste of the fruits (Crisosto et al., 2002). From this point of view, the present results that ranged within the interval 25.19639.677, sustained the conclusion of the fruit being considered of high quality, and thus well appreciated.

The total content of polyphenols has a particular importance in determining the sweet cherries taste and flavour, along with an antioxidant role with anticancer effect (Chaovanalikit and Wrolstad, 2004). Other studies reported large variations of polyphenols in investigated sweet cherry cultivars (Kim et al., 2005; Melicháčová et al., 2010; Skrzyński et al., 2016).

\section{Conclusions}

Due to the increased genetic variability in the sweet cherry species and a strong heterozygotism in the cultivars 'Van' and 'Boambe de Cotnari', the hybridization has allowed the obtaining of nine extremely valuable cultivars, that got remarked by earliness ('Cetățuia', 'Cătălina'), decreased trees' vigour ('Ştefan', 'Golia'), particular quality of the fruits ('Ludovan', 'Iaşirom', 'Golia', 'Bucium', 'Stefan', 'Oana', 'Radu') and resistance to diseases and frost ('Bucium', 'Iaşirom'). Hence, they can be recommended for launching fruit-growing plantations with large density per hectare, in areas with different pedoclimatic conditions.

\section{Acknowledgements}

The present work was partially supported by the Romanian Ministry of Agriculture and Rural Development, Grant No. ADER 3.2.2./2015, with title 'Fruit tree species improvement to increase food safety and security'.

\section{References}

Bieniek A, Kawecki Z, Kopytowski J, Zielenkiewicz J (2011). Yielding and fruit quality of Lithuanian sweet cherry cultivars grown under the climatic and soil conditions of Warmia. Folia Horticulturae 23(2):101106. 
212

Budan S, Balaci R, Petre L (1997). Genetic breeding achievements in cherry and sour cherry tree. In: Romanian contributions in genetic breeding of cultivars and rootstocks of fruit growing tree, small fruits and strawberry (1951-1996) [in Romanian]. Piteşti.

Budan S, Grădinariu G (2000). The cherry tree [in Romanian]. Ed Ion Ionescu dela Brad, Iaşi.

Cociu V, Oprea Ş (1989). Research methods in fruit tree breeding [in Romanian].EdDacia, Cluj-Napoca.

Cociu V, Botu I, Şerboiu L (1999). Progress in breeding of horticultural plants in Romania [in Romanian]. Ed Ceres, Bucureşti.

Chaovanalikit A, Wrolstad RE (2004). Total anthocyanins and total phenolics of fresh and processed cherries and their antioxidant properties. Journal of Food Science 69(1):C67-72.

Crisosto CH, Crisosto GM, Ritenour MA (2002). Testing the reliability of skin color as an indicator of quality for early season 'Brooks' (Prunus avium L) cherry. Postharvest Biology and Technology 24:147-154.

Darbyshire R, Webb L, Goodwin I, Barlow EWR (2012). Evaluation of recent trends in Australian pome fruit spring phenology. International Journal of Biometeorology 57(3):409-421.

Demirsoy H, Demirsoy L (2004). Characteristics of some local sweet cherry cultivars from homeland. Journal of Agronomy 3:88-89.

Faniadis D, Drogoudi PD, Vasilakakis M (2010). Effects of cultivar, orchard elevation, and storage on fruit quality characters of sweet cherry (Prunus avium L.). Scientia Horticulturae 125:301-304.

Fleckinger J (1960). Phénologie et arboriculture fruitière. In: Le Bon Jardinier,EdMaison rustique, Paris, pp 362-372.

Fotirić Akšić M, Nikolić T (2013). Analysis of pomological traits in new promisingsweet cherry genotypes. Genetika 45(3):873-880.

García F, Frutos D, Lopez G, Carrillo A, Cos J (2014). Flowering of sweet cherry (Prunus aviumL.) cultivars in Cieza, Murcia, Spain. Acta Horticulturae 1020:191-196.

Ghimicescu G (1977). The chemistry and analysis of food, beverages and spices [in Romanian]. Ed Junimea, Iaşi.

Grădinariu G, Istrate M (2003). Special crop of fruit growing trees [in Romanian].EdMatrix Rom, Bucureşti.

Jayaprakasha GK, Singh RP, Sakariah KK (2001). Antioxidant activity of grape seed (Vitis vinifera) extracted on peroxidation models in vitro. Food Chemistry 73:285-290.

Jänes H, Ardel P, Kahu K, Kelt K, Kikas A (2010). Some biological properties and fruit quality parameters of new sweet cherry cultivars and perspective selections. Agronomy Research 8(Sp Iss III):583-588.
Kask K, Jänes H, Libek A, Arus L, Kikas A, Kaldmäe H, Univer N, Univer $T$ (2010). New cultivars and future perspectives in professional fruit breeding in Estonia. Agronomy Research 8(Sp Iss III):603-614.

Kim DO, Heo HJ, Kim YJ, Yang HS, Lee CY (2005). Sweet and sour cherry phenolics and their protective effects on neuronal cells. Journal of Agricultural and Food Chemistry 53(26):9921-9927.

Meland M, Kaiser C, Christensen MJ (2014). Physical and chemical methods to avoid fruit cracking in cherry. AgroLife Scientific Journal 3(1):177-183.

Milatović D (2011). Breeding and cultivars in cherry. In: Sweet and sour cherry tree [in Serbian]. Ed Naučno voćarsko društvo Srbije, Čačak, Srbije pp 119-213.

Melicháčová S, Timoracká M, Bystrická J, Vollmannová A, Čér YJ (2010). Relation of total antiradical activity and total polyphenol content of sweet cherries (Prunus avium L.) and tart cherries (Prunus cerasus L.). Acta AgriculturaeSlovenica 95(1):21-28.

Petre L, Sìrbu S, Iurea E (2007). Physical, chemical and technological features of fruits for the cherry breeds and hybrid elites created at RSFG iasi, romania. Lucrari Stiintifice USAMV Iasi, Series Horticulture 50:603610.

Prskavec K, Kloutvor J (1986). 30 years survey of spring frost occurrence during cherry blossom period. In: New Trends in Cherry Growing. Sempra, Praga.

Sansavini S, Lugli S (2008). Sweet cherry breeding programs in Europe and Asia. Acta Horticulturae 795:41-57.

Schuster M, Grafe C, Wolfram B, Schmidt H (2014). Cultivars resulting from cherry breeding in Germany. Erwerbs-Obstbau 56(2):67-72.

Sen F, Oksar RE, Golkarian M, Yaldiz S (2014). Quality changes of different sweet cherry cultivars at various stages of the supply chain. Notulae Botanicae Horti Agrobotanici 42(2):501-506.

Skrzyński J, Leja M, Gonkiewicz A, Banach P (2016). Cultivar effect on the sweet cherry antioxidant and some chemical attributes. Folia Horticulturae 28(1):95-102.

UPOV (2006). Sweet Cherry (Prunus avium L.). Guidelines for the conduct of tests for distinctness, uniformity and stability. TG 35/7 UPOVGeneva. 